\title{
A psychological typology of females diagnosed with anorexia nervosa, bulimia nervosa or binge eating disorder
}

\section{BACKGROUND}

The present paper reports the results of research aimed at identifying intra-group differences among females suffering from different eating disorders (anorexia nervosa, bulimia nervosa or binge eating disorder) in terms of the subjects' psychological traits, adoption of socio-cultural norms (through media pressure, internationalization of norms, and exposure to information concerning body image standards), and the level of body dissatisfaction. The following research question was asked: is it possible to distinguish specific profiles of psychological characteristics, as well as levels of body dissatisfaction, social pressure, media exposure and internalization of common standards of body image?

PARTICIPANTS AND PROCEDURE

The clinical population consisted of 121 females aged 2026. The research was conducted in the years 2007-2012. The following research methods and procedures were applied: 1) a clinical interview, 2) the Contour Drawing Rating Scale, 3) the Eating Disorder Inventory (EDI), 4) a Polish translation of the Socio-cultural Attitudes Towards Appearance Questionnaire (SATAQ-3).

\section{RESULTS}

Cluster analysis of the research data allowed four significantly different clusters to be distinguished in the group of 121 examined females suffering from eating disorders. In the next step, analysis of variance (the ANOVA test) was used to compare the differences between the examined clusters in terms of the investigated variables and their indicators.

\section{CONCLUSIONS}

Due to significant differences between the examined females in terms of the strength levels and the configuration of psychological and socio-cultural variables investigated in the present study, the females were classified into four different psychological types referred to as neurotic, perfectionist, impulsive and adolescent-narcissistic.

\section{KEY WORDS}

psychological typology; attitude towards one's own body; socio-cultural influence; anorexia nervosa; bulimia nervosa; binge eating disorder

organizations - Department of Clinical and Forensic Psychology, University of Silesia in Katowice, Katowice, Poland Authors' Contribution - A: Study design - B: Data collection - C: Statistical analysis - D: Data interpretation .

E: Manuscript preparation · F: Literature search · G: Funds collection

CORRESPonding AUthor - Bernadetta Izydorczyk, Ph.D., Department of Clinical and Forensic Psychology, University of

Silesia in Katowice, 53 Grażyńskiego Str., 40-126 Katowice, Poland, e-mail: b.izydorczyk@interia.pl

TO CITE THIS ARTICLE - Izydorczyk, B. (2015). A psychological typology of females diagnosed with anorexia nervosa,

bulimia nervosa or binge eating disorder. Health Psychology Report, 3(4), 312-325. DOI: 10.5114/hpr.2015.55169

RECEIVED 25.08.2015 - REVIEWED 21.09.2015 - ACCEPTED 16.10.2015 · PUBLISHED 02.11.2015 


\section{BACKGROUND}

The present paper addresses the issue of differences in terms of psychological traits and attitudes towards a socio-cultural impact of the mass media on the accepted standards of body image and appearance among females suffering from different types of eating disorders (anorexia nervosa, bulimia nervosa and binge eating disorder). In reviewing the Polish literature, limited data were found from research studies aimed at detailed empirical investigation of the profiles of specific psychological traits as well as body-related attitudes and behaviours in individuals diagnosed with anorexia nervosa, bulimia nervosa or binge eating disorder. There are only reports of studies conducted in small samples of subjects diagnosed with the aforementioned eating disorders. As mentioned in the literature review, there are no epidemiological studies conducted on a randomly selected Polish population sample. There is also lack of research studies which would reveal the real incidence of eating disorders in the population.

Modern theoretical conceptions of eating psychopathologies emphasize that development of specific psychological mechanisms and profile characteristics of individuals suffering from eating disorders is determined by numerous factors (Garner, 2004; Izydorczyk, 2014). In the light of the literature, body image disturbances are regarded as a significant factor behind development of the eating disorders discussed in the present paper, which is emphasized by contemporary psychoanalytic (Krueger, 2002a,b), cognitive (Thompson, 2004; Cash, 2011a,b, Tiggemann, 2003; Thompson \& Berg, 2002; Thompson \& Stice, 2001; Thompson \& Smolak, 2001) as well as socio-cultural conceptions (Fredrickson \& Roberts, 1997; Fredrickson, \& Harrison, 2005; McKinley, \& Hyde, 1996; Włodarczyk-Bisaga, Dolan, \& McCluskey, 1995; Wolf, 2000, 2002; Żabiński et al., 2001).

Epidemiological data provided by source references confirm the significant prevalence of eating disorders in the population of girls and young females (Józefik, 1999 as cited in: Lwow, Dunajska, \& Milewicz, 2007; Kołobo \& Wojnarowska, 2004; Wojtyła, Biliński, Bojar, \& Wojtyła, 2011). It is believed that unhealthy food- and eating-related behaviours exhibited by adult and teenage females are frequently triggered by the individuals' inability to accept their actual body image and a strong need to attain a perfect body image created by psychological and socio-cultural factors, which is addressed in the current paper. Research data described in the subject literature point to body perception disturbances among teenagers. Specific psychological traits together with distorted body perception and negative body image are believed to contribute to development of eating disorders. Therefore applied research aimed at dis- tinguishing the psychological factors which would support the diagnosis and treatment of patients with the aforementioned eating disorder seems to acquire increasing significance. Taking into consideration the major factors contributing to the treatment of individuals suffering from anorexia nervosa, bulimia nervosa or binge eating disorder, the current study, aimed at distinguishing psychological types of females suffering from the aforementioned eating disorders (irrespective of the medical diagnosis of the particular type of an eating disorder), is likely to facilitate effective therapy for individuals diagnosed with eating disorders. Taking into consideration a specific profile of psychological characteristics of the aforementioned individuals (which in the present study is referred to as a psychological type) in the process of treatment which includes psychological therapy will allow the most effective form of psychotherapy to be selected for this group of patients. The configuration of the patient's psychological characteristics and socio-cultural attitudes towards his or her own body is likely to affect the process of selection of the most desirable form of psychotherapy for the individual. A long-term (group or individual) psychodynamic psychotherapy might prove effective in the treatment of a certain group of patients, whereas in the case of individuals exhibiting a different configuration of psychological characteristics, a short-term insight-oriented therapy is likely to be a more appropriate form of treatment. If the individual's psychological profile proves to be dominated by a high level of impulsiveness and bulimic thoughts, it is recommended that psychodynamic psychotherapy for the person be supported by cognitive-behavioural therapy. Although it is important to apply an eclectic approach in treatment designed for patients diagnosed with eating disorders, similar significance should be attached to the process of selecting an appropriate form of psychological therapy, which would involve considering the configuration of psychological characteristics displayed by the patients. The nature of the present applied study determined formulation of the research questions and objectives.

\section{RESEARCH QUESTIONS AND OBJECTIVES}

The present research was aimed at identifying intra-group differences between females suffering from different eating disorders (anorexia nervosa, bulimia nervosa or binge eating disorder) in terms of the subjects' psychological traits; adoption of socio-cultural norms (through media pressure, internationalization of norms, and exposure to information concerning body image standards); as well as the level of body dissatisfaction. The following research question was asked: is it possible to distinguish specific profiles
A psychological typology anorexia, bulimia 
Bernadetta Izydorczyk of psychological characteristics, as well as levels of body dissatisfaction, social pressure, media exposure and internalization of common standards of body image? The present study aimed at specifying similarities and differences between the subjects in terms of the investigated psychological and socio-cultural variables, irrespective of the types of eating disorders the examined females had been diagnosed with.

The data provided by source references indicate that individuals suffering from eating disorders exhibit specific psychological characteristics such as perfectionism, interoceptive awareness deficits, a tendency towards bulimia, the fear of gaining weight, maturity fear, low self-evaluation and distrust in establishing interpersonal relationships. Patients diagnosed with anorexia nervosa and bulimia nervosa also display certain body-related behaviours and attitudes they adopt under the influence of socio-cultural norms regarding body image, which points to an increased level of internalization and social pressure in this group of patients. This can be supported by the findings of the studies conducted by Bulik et al. (2003), Duncan et al. (2005), Garner (2004), Grilo (2002), Cash and Pruzinsky (2002), Krueger (2002a,b), Izydorczyk (2010, 2011,a,b,c, 2013), Mikołajczyk and Samochowiec (2004), as well as Ogińska-Bulik and Chanduszko-Salska (2000a,b) and Ogińska-Bulik (2004).

Based on the data described in the subject literature, it was possible to develop a theoretical model and define dependent and independent variables investigated in the present study.

In the present research, medically diagnosed eating disorders (according to the ICD 10 criteria of psychiatric classification) such as anorexia nervosa, bulimia nervosa and binge eating disorder constituted the main dependent variables.

The main independent variable investigated in the current study was defined as a psychological type of a person diagnosed with an eating disorder. The definition resulted from the author's attempt to investigate the differences and similarities between individuals suffering from anorexia nervosa, bulimia nervosa and binge eating disorder in terms of their psychological characteristics and socio-cultural attitudes towards their own bodies. Moreover, it was expected that as a result of statistical cluster analysis it would be possible to distinguish in the examined population of females certain clusters of subjects, and classify them into different psychological types, based on the individuals' psychological characteristics and body-related behaviours.

Hence, the main independent variable was defined as a complex one and consisted of three components. One of them was a cluster of psychological traits exhibited by individuals suffering from anorexia nervosa, bulimia nervosa and binge eating disorder. The characteristics examined in the present study were selected based on the subject literature and source references (Cash, 2002; Thompson, 2004; Garner, 2004). The psychological traits characteristic of the examined types of eating disorders included:

1. Perfectionism - referred to as the tendency to hold exceptionally high expectations, and to live up to the highest possible standards in order to gain personal achievements in life;

2. Interoceptive awareness - measures the ability of an individual to discriminate between sensations and feelings, and between the sensations of hunger and satiety; it also refers to the feeling of perplexity accompanying the process of recognizing and responding to emotional states and body sensations;

3. Bulimia - a psychological variable referred to as preoccupation with food and overeating as a result of frustration and emotional dejection, usually followed by the need to engage in compensatory behaviours aimed at body weight loss and ridding oneself of the food consumed;

4. Self-evaluation - a psychological variable describing a level of an individual's feelings of ineffectiveness, inadequacy, insecurity and low self-esteem;

5. Interpersonal relations - a psychological variable describing a level of insecurity and interpersonal distrust. It is described as an individual's feeling of alienation, and reluctance to form close relationships, as well as discomfort with expressing personal thoughts and feelings in the company of other people;

6. Fear of gaining weight - a psychological variable which describes an individual's level of drive for thinness;

7. Maturity fear - described as regressive tendencies in an individual (i.e. a desire to regain childhood security), and referred to as the person's fear of facing the demands of adult life (i.e. approval of psychosexual development and the body image changes as well as the role of physical appearance, accompanying the process of transition to the stage of maturity).

The second independent variable was defined as cognitive and emotional attitudes of the examined female towards her self-body image and appearance. The variable strength level and direction were reflected by intensity of the subject's feelings towards her own body, represented by the level of the person's body satisfaction or dissatisfaction. Body dissatisfaction is interpreted as a tendency to experience negative emotions regarding one's own body and appearance. The study subjects' thoughts about their own bodies was reflected by their body image self-evaluation, represented by a degree of discrepancy between the females' actual appearance and the ideal body image they desired. The empirical definition of the aforementioned variable was based on theoretical 
and empirical data gathered by Thompson as a result of many years' research (Thompson, 2004).

The third independent variable was defined as socio-cultural attitudes towards appearance and the body - the characteristic which refers to affective and cognitive processes and the body-related behaviours and attitudes which an individual adopts under the influence of socio-cultural factors (Cash, 2002; Thompson, 2004). The indicators of this variable included:

- internalization of socio-cultural norms concerning body image, defined as conscious or subconscious acceptance of standards regarding body and appearance, internalized as a personal belief system concerning the common societal standards of body image;

- media exposure - described as the amount of written, audio or visual information (messages) received by an individual through the media (exposure to the ideas and messages concerning current standards of body and appearance, portrayed in the mass media); - pressure of socio-cultural norms - the so-called social pressure, understood to mean the influence of the information provided by the media concerning socio-cultural standards regarding body image on the subject's thoughts about her own body and appearance; and on the body-related behaviours the individual adopts under the influence of the messages concerning attractive female appearance.

An additional control variable examined in the present study was body mass index (BMI). Its value is calculated as the individual's body weight, measured in kilograms, divided by the square of his or her height, measured in metres (Gajewski, 2013).

\section{PARTICIPANTS AND PROCEDURE}

\section{RESEARCH POPULATION}

The subjects were selected intentionally. The clinical (research) population consisted of 121 females aged 20-26, with similar socio-cultural status (studying and/or working temporarily or permanently, residing in a city environment for at least five years, with access to mass media promoting the standards regarding body and appearance established for highly industrialized countries).

The examined females exhibited symptoms of the following medically diagnosed eating disorders:

- anorexia nervosa (according to the ICD 10 F.50.0; F51 criteria of psychiatric classification), including a restrictive type $(n=29$, age: $21.30, \mathrm{BMI}=16.70)$ and a bulimia type ( $n=30$, age: $22.30, \mathrm{BMI}=17.80)$; - bulimia nervosa (according to the ICD 10 F.50.2; F50.3 criteria of psychiatric classification; $n=30$, age: $21.30, \mathrm{BMI}=20.63$ );

- binge eating disorder (according to the ICD 10 F.50.4 criteria of psychiatric classification; $n=32$, age: $24.10, \mathrm{BMI}=24.03$ ).
The research was conducted in the years 20072012 , in outpatient clinics for treatment of neurosis and eating disorders as well as in neurosis and eating disorder treatment centres in Poland (predominantly in the Upper Silesia and Małopolska regions). Due to the clinical character of the research, the study was approved by the Ethics Committee of Silesian University.

\section{RESEARCH METHODS AND PROCEDURES}

The methods applied in the present research included a clinical method (an interview and projective tests) as well as psychometric techniques (questionnaires aimed at examining psychological characteristics and socio-cultural attitudes towards body and appearance). The variable measurement methods applied in this study have been described in the subject literature. A more elaborate description of the Socio-cultural Attitudes Towards Appearance Questionnaire (SATAQ-3) is presented in this paper, since a Polish version of the instrument was developed for the purpose of the current research. Therefore, its detailed statistical parameters are provided in the article (reliability and validity ratios). Other questionnaires (the Eating Disorder Inventory and the Contour Drawing Rating Scale) were regarded as appropriate for measuring the variables investigated in the present research, based on the data concerning their reliability and validity described in the subject literature (Garner, 2004; Thompson, 2004).

1. A clinical interview, aimed at measuring the subjects' BMI and examining socio-demographic data including the study participants' age, marital status and residential environment.

2. The Contour Drawing Rating Scale devised by Thompson and Gray was applied to examine the cognitive aspect of the subjects' attitudes towards their appearance, i.e. to evaluate the participants' perception of their body image. It allowed a comparison to be made between the actual body image (the "actual me" image), perceived by the study subject, and the person's ideal body image ("what I would like to look like”) (Thompson et al., 1991). The instrument has been applied several times in research studies conducted in the USA, aimed at measuring body image and body-related attitudes (Thompson \& Gray, 1995; Thompson \& Altabe, 1999).

3. The Eating Disorder Inventory (EDI) devised by David Garner, Marion P. Olmsted, and Janet Polivy, adapted by Cezary Żechowski in 2008; aimed at measuring the strength and direction of the examined individual's emotional attitude towards body image, represented by the level of the person's body satisfaction or dissatisfaction; as well as the level of the subject's psychological traits including interoceptive awareness, bulimia,
A psychological typology anorexia, bulimia 
perfectionism, self-evaluation (the level of an individual's feelings of ineffectiveness and inadequacy), interpersonal relations (the feelings of interpersonal distrust and insecurity), the fear of gaining weight (an increased level of drive for thinness), and maturity fear (Garner, 2004; Grogan, 2008; Żechowski, 2008). Internal consistency and reliability of the EDI proves to be high (Wear \& Pratz, 1987; Crowther \& Sherwood, 1997). The values of Cronbach's $\alpha$ for all subscales of the Polish version of the inventory devised by Żechowski (2008) were found to be high and satisfactory. They ranged from .92 ("body dissatisfaction") to .61 ("interpersonal distrust").

4. A Polish translation of the Socio-cultural Attitudes Towards Appearance Questionnaire (SATAQ-3), devised by Kevin Thompson et al., aimed at measuring the level of socio-cultural influence on body-related attitudes among the examined females (Heinberg, Thompson, \& Stormer, 1995). In the first step the SATAQ-3 questionnaire was translated into Polish and back into English. Prior to applying the instrument in full-scale research, a pilot study was conducted in a population of 140 females aged 18-26, exhibiting no symptoms of eating disorders, which was aimed at testing adequacy of the aforementioned measurement instrument. The questionnaire comprised 24 items describing the major symptoms of the process of adoption of socio-cultural norms regarding the body, in reference to the following dimensions: internalization, pressure and the level of the individual's exposure to the information concerning common socio-cultural standards of body image and appearance promoted by the media. The items constituted three scales: 1) the Internalization scale, 2) the Pressure scale, and 3) the Exposure to information scale. The results obtained have been subjected to reliability analysis. The Kaiser-Meyer-Olkin (KMO) test and the Bartlett's test of sphericity were applied to assess the sampling adequacy. The KMO measure reached the value of 98. The result of Bartlett's test of sphericity allowed the unit matrix hypothesis to be rejected $\left(\chi^{2}=3046.28, d f=276, p<.001\right)$. The aforementioned results provided grounds for performing an exploratory factor analysis, using the principal-axis factoring method, employing Varimax rotation with Kaiser normalization.

Based on statistical techniques of factor estimation, and scree plot examination, the following three factors, labelled subscales, were singled out: internalization of socio-cultural norms, pressure of socio-cultural norms, and exposure to information concerning body image, i.e. the level of the subject's exposure to the ideas and messages concerning current standards of body and appearance portrayed in the mass media. The subscales showed a high level of reliability indicators, as Cronbach's $\alpha$ exceeded .92. The "pressure of social norms" scale consisted of seven items, whereas the scale of "media exposure" comprised eight items. One hundred and twenty one research subjects suffering from eating disorders were examined using the aforementioned questionnaire.

Selection of the research methods was determined by psychometric criteria as well as the criteria of clinical interpretation of the research data obtained using a questionnaire and a clinical (projective) method. The criteria allowed determination of the strength levels of all variables investigated in the study in the dimension of: appropriate-inappropriate for maintaining good health (indicative of the variable strength level defined as clinical - inappropriate for maintaining good health). Clinical analysis of the research data was conducted using a quartile method.

In the first stage of the research procedure, the central tendency in the data set was measured using the arithmetic mean and median, which provided sufficient information regarding the distribution of the examined indicators, and allowed measurement of their strength levels as well as their allocation across quartiles into four clinically meaningful categories: - very high clinical level - referring to very high scores lying in quartile 4, describing a very high and inappropriate level of the examined variable indicator;

- high clinical level - concerning elevated values, categorized in quartile 3, denoting inappropriately high level of the investigated indicator;

- elevated clinical level - referring to average scores falling in the second quartile, indicating an increased strength level of the variable indicator (the quartile contained values defined as borderline cases between appropriate and inappropriate);

- average (non-clinical) level - regarding low scores, lying within the first quartile, classified as appropriate (within normal values).

It should be emphasized that the mean values with respect to the body self-evaluation defined as ideal body image were interpreted reversely, i.e. the lower the score, the higher the negative body image in the examined females. In clinical analysis of the research data, mean values ranging from 2.00 to 2.19 were interpreted as very high, whereas values between 2.20 and 2.60 were considered to be high. This suggests that the image most frequently chosen by the subjects in Thompson and Grey's Figure Test was the one representing the slimmest or even emaciated body shape.

Cluster analysis of the data obtained as a result of this research allowed four significantly different clusters to be distinguished in the group of 121 examined females suffering from eating disorders. 


\section{RESULTS}

Psychometric and clinical analysis of intra-group differences between the examined females was performed using the k-means method. Due to the fact that the variables were measured on different scales, raw data were standardized and underwent further statistical examination. As a result of $\mathrm{k}$-means analysis of the research data, different clusters were distinguished. In the next step, analysis of variance (the ANOVA test) was used to compare the differences between the examined clusters in terms of the investigated variables and their indicators.

Figure 1 presents standardized mean values for those study variables which proved to be statistically different across clusters. The clusters which were homogenous in terms of the strength level and the configuration of the indicators of the investigated variables are not shown in the figure. Table 1 presents specification of significant differences regarding the standardized mean values describing psychological and socio-cultural characteristics as well as the strength level of negative body image (body dissatisfaction and negative self-evaluation) in the population of Polish females suffering from eating disorders $(N=121)$, considering the cluster classification of the examined individuals. Table 2 shows the criteria of clinical examination of the strength levels of the psychological and socio-cultural factors.
Statistical cluster analysis conducted using the $\mathrm{k}$-means demonstrated significant differences between the examined females in the four clusters in terms of age, BMI index, psychological traits and socio-cultural attitudes towards body and appearance. Due to significant differences among the research subjects comprising the four clusters in terms of the strength level and configuration of psychological and socio-cultural variables examined in the study, the females were classified into four different psychological types referred to as neurotic (cluster 1), perfectionist (cluster 2), impulsive (cluster 3), and adolescent-narcissistic (cluster 4). Analysis of the intra-group differences between the females classified into particular clusters confirmed that the research subjects categorized as neurotic exhibited the highest mean body weight and BMI values (indicating overweight), whereas the study participants referred to as neurotic were discovered to have the lowest average body weight and BMI index, which pointed to the lower limit of the level of underweight. The mean body weight and BMI values in the group of subjects identified as impulsive were found to be in the lower limit of the normal range, whereas the females defined as adolescent-narcissistic exhibited a similar mean body weight and BMI index as those classified as perfectionist (which indicated underweight). The examined individuals who were classified as perfectionist (cluster 2) turned out to be the oldest study participants.

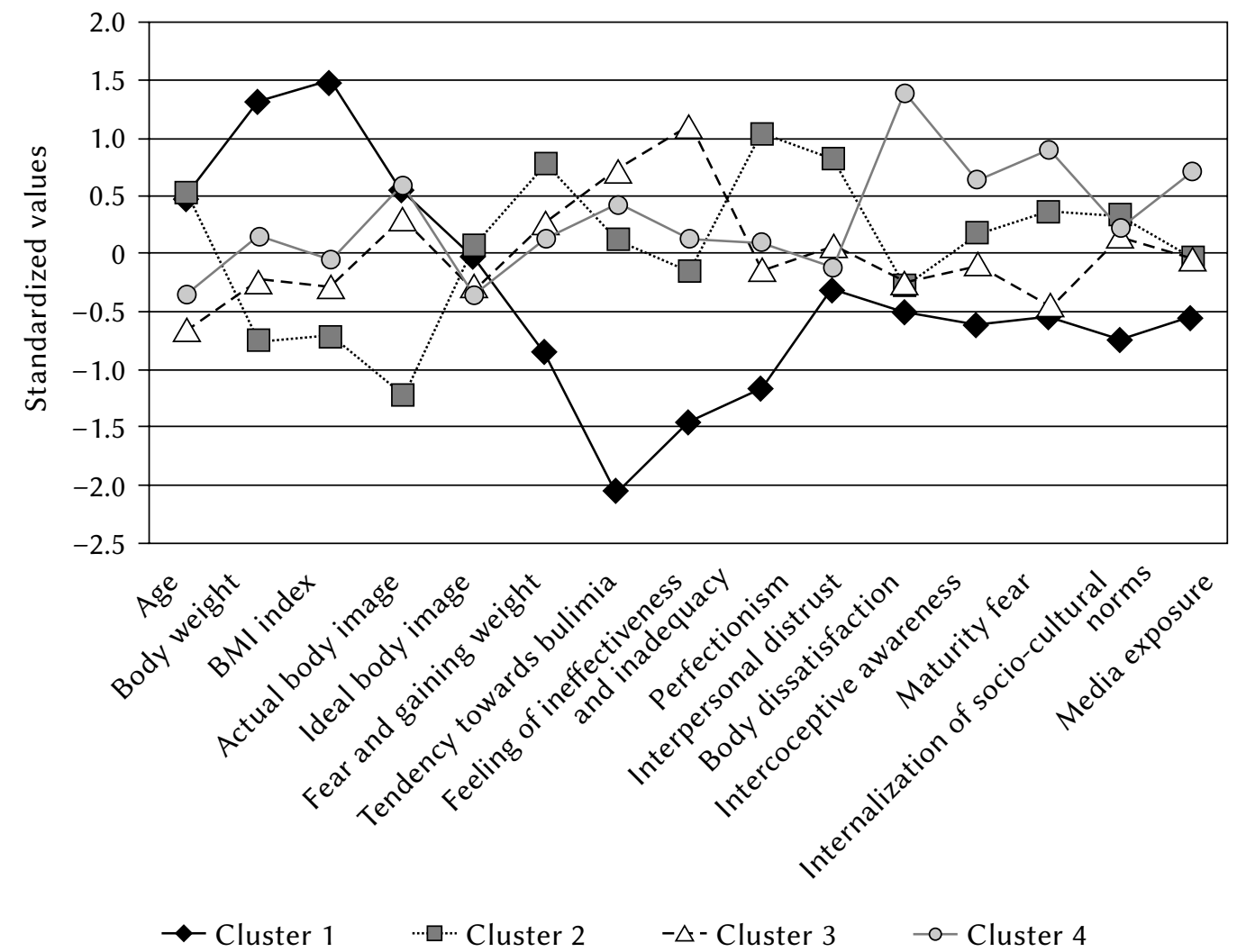

Figure 1. Graphic illustration of cluster analysis conducted using the k-means method. Specification of significant indicators of diversity within the examined population of females with eating disorders $(N=121)$. 
Table 1

Results of cluster analysis conducted using the k-means method. Specification of significant differences regarding the standardized mean values of psychological and socio-cultural variables between the examined Polish females suffering from eating disorders $(N=121)$

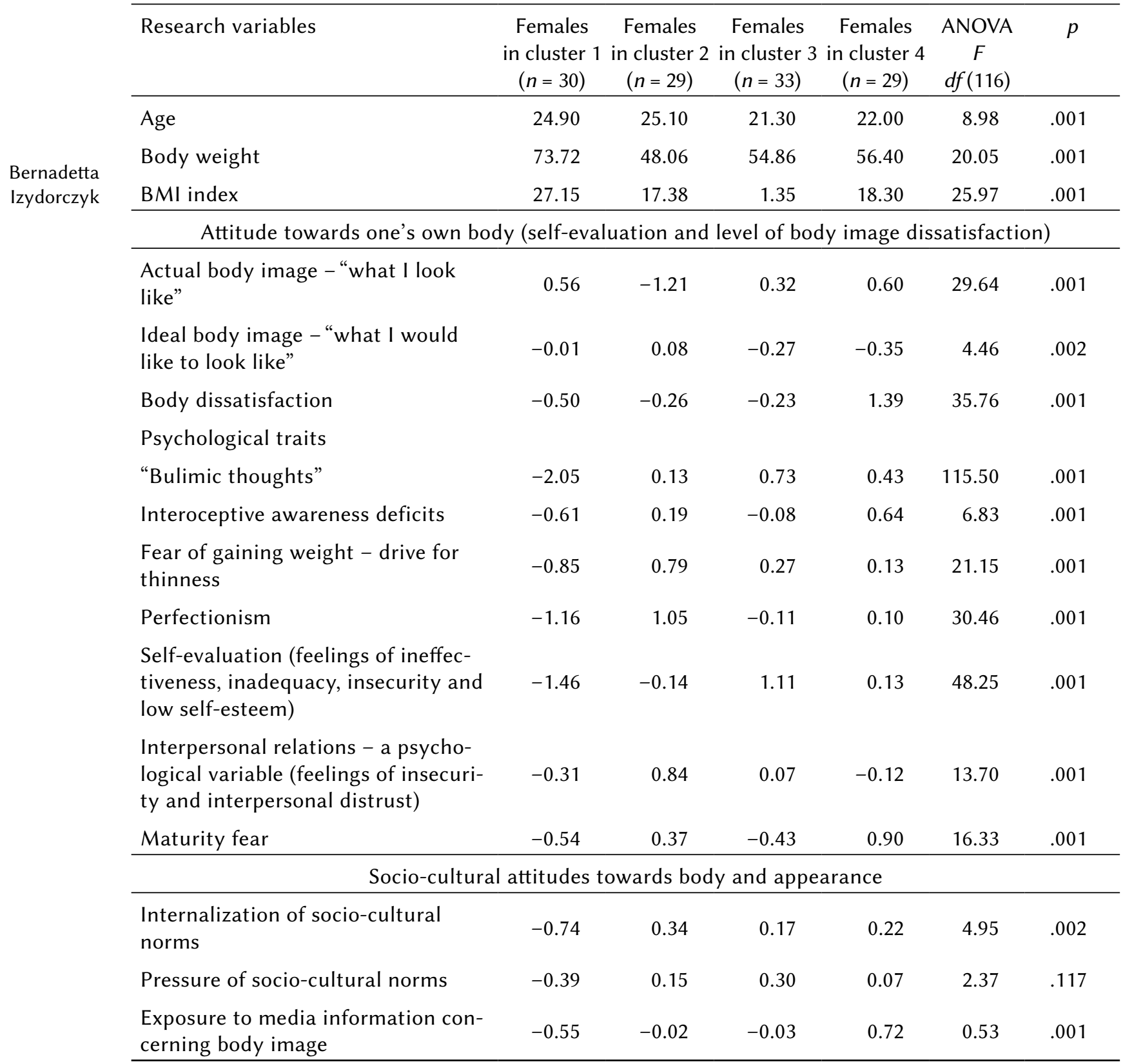

Neurotic females categorized as cluster 1 were found to be slightly younger than those in cluster 2 . It was found that the examined females comprising cluster 1 and cluster 2 were aged between 24 and 26. The females' mean age suggested early adulthood, which in most individuals denotes a life stage characterized by a completed separation-individuation process and development of multi-aspect adult (personal, social and professional) identity, autonomy, as well as adopting adult roles (e.g. those related to family and maternity). The study participants classified as impulsive and ad- olescent-narcissistic were discovered to be the youngest. The average age in these groups ranged between 21 and 22, which points to the stage of life and mental development referred to as the period of late adolescence (Blos, 1967; Bee, 2004).

Cluster analysis of the research data concerning three socio-cultural attitudes describing the impact of socio-cultural factors on body-related behaviours revealed significant differences between the examined females only in terms of internalization of socio-cultural norms and exposure to media informa- 
Table 2

Strength levels of examined psychological and socio-cultural variables in four types of females with eating disorders, distinguished as a result of the present study $(N=121)$

\begin{tabular}{|c|c|c|c|c|}
\hline Psychological and socio-cultural variables & $\begin{array}{l}\text { Neurotic } \\
\text { type } \\
(n=30)\end{array}$ & $\begin{array}{c}\text { Perfectionist } \\
\text { type } \\
(n=29)\end{array}$ & $\begin{array}{l}\text { Impulsive } \\
\text { type } \\
(n=33)\end{array}$ & $\begin{array}{l}\text { Adoles- } \\
\text { cent-narcis- } \\
\text { sistic type } \\
(n=29)\end{array}$ \\
\hline \multicolumn{5}{|c|}{ Attitude towards one's own body - self-evaluation and level of body dissatisfaction } \\
\hline Body dissatisfaction & elevated & high & high & very high \\
\hline Actual body image & very high & low & high & high \\
\hline Ideal body image & high & very high & very high & very high \\
\hline \multicolumn{5}{|c|}{ Psychological traits } \\
\hline Interoceptive awareness & elevated & high & high & high \\
\hline Perfectionism & elevated & very high & high & high \\
\hline Fear of gaining weight & elevated & very high & high & high \\
\hline "Bulimic thoughts" & elevated & elevated & high & elevated \\
\hline $\begin{array}{l}\text { Self-evaluation - ineffectiveness and low } \\
\text { self-evaluation }\end{array}$ & elevated & elevated & high & elevated \\
\hline $\begin{array}{l}\text { Interpersonal relations (feelings of insecurity } \\
\text { and interpersonal distrust) }\end{array}$ & elevated & elevated & elevated & elevated \\
\hline Maturity fear & very high & very high & elevated & very high \\
\hline \multicolumn{5}{|c|}{ Socio-cultural attitudes towards body and appearance } \\
\hline Internalization of socio-cultural norms & very high & high & very high & high \\
\hline Pressure of socio-cultural norms & high & elevated & very high & high \\
\hline $\begin{array}{l}\text { Exposure to media information concerning } \\
\text { body image }\end{array}$ & very high & very high & very high & very high \\
\hline
\end{tabular}

tion regarding body image. No significant differences were discovered between the study subjects in terms of the pressure of socio-cultural norms. The females characterized as neurotic were found to exhibit the lowest level of internalization of socio-cultural standards, while in the group of subjects classified as perfectionist it proved to be the highest. The study participants categorized as impulsive and adolescent-narcissistic demonstrated a similar level of internalization of socio-cultural norms.

As far as exposure to media information concerning appearance is concerned, it reached its highest value in the study participants classified into an adolescent-narcissistic type. Neurotic females were found to exhibit the lowest level of the examined variable. The perfectionist and impulsive subjects proved to display a similar level of media exposure, which pointed to certain similarities between the individuals. Socio-cultural pressure failed to be a significant indicator of diversity within the examined population of females with eating disorders.

\section{DISCUSSION}

Empirical data gathered as a result of this research allowed four different psychological types to be distinguished among females who suffer from various eating disorders. It was discovered that individuals who exhibit a high level of such characteristics as perfectionism, the fear of gaining weight and body dissatisfaction are classified into a perfectionist or an adolescent-narcissistic type. The aforementioned psychological characteristics are frequently exhibited by patients diagnosed with anorexia nervosa (especially a restrictive type). Similar findings were reported by such researchers as Bulik et al. (2003), Fairburn and Harrison (2003), Garner (2004), Grilo (2002), Mikołajczyk, Samochowiec, Śmiarowska, and Syrek (2004), Izydorczyk (2010, 2011a,b, 2013) and Lipowska and Lipowski (2013).

The individuals classified into an impulsive type were found to display such psychological characteristics as bulimic thoughts, impulsiveness of emotional responses (low interoceptive awareness) as well as low
A psychological typology anorexia, bulimia 
Bernadetta Izydorczyk self-evaluation. This group of study participants comprised predominantly females suffering from bulimia. A similar discovery was made by Duncan et al. (2005). Such characteristics as body negation and body dissatisfaction, displayed by the research participants classified into a neurotic type, were also investigated by Ogińska-Bulik and Chanduszko-Salska (2000a,b; 2004).

In the literature there are numerous theories emphasizing the role of cultural factors in the development of body-related attitudes and behaviours. Cultivation theory, developed by Gerbner et al. in 1994 (Gerbner, Gross, Morgan, \& Signorielli, 1994) suggests that the mass media shape peoples' conceptions of social reality. Once exposed to the information provided by the mass media or other socialization sources (e.g. a peer group or a family), an individual gradually develops a view of reality (including beliefs and opinions concerning appearance and his or her own body image) that seems to be close or identical to the images depicted by the media. The theories emphasize the role of media messages in focusing attention of female teenagers and women on certain themes, and simultaneously shaping their awareness of significant and insignificant issues.

It is also important to mention feminist constructivist psychodynamic theories (Jordan, Kaplan, Miller, Stiver, \& Surrey, 1991; Hare-Mustin \& Marecek, 1988). They emphasize the impact of cultural messages regarding femininity on the relationships between males and females. When analyzing the issue of body image, it is important to refer to the sexual objectification theory, which describes the influence of socio-cultural factors on sexualization (objectification) of the female body (Fredrickson \& Roberts, 1997; Fredrickson \& Harrison, 2005; Zurbriggen et al., 2010).

As regards the variable describing the subjects' attitudes towards their own bodies and appearance, certain difference were detected between the females classified into four different psychological types in terms of the cognitive aspect of body image self-evaluation (represented by the degree of discrepancy between the individuals' actual appearance and the ideal body image they desired) as well as the participants' emotional body dissatisfaction. It was also found that the examined females were significantly different in terms of the following psychological factors: the fear of gaining weight (excessive drive for thinness), a tendency towards bulimia, perfectionism, interoceptive awareness deficits, maturity fear, low self-esteem and the feelings of ineffectiveness and inadequacy, as well as the feelings of insecurity and distrust in interpersonal relationships.

Table 2 presents clinical interpretation of the mean values regarding the psychological and socio-cultural variables which significantly differentiate the four clusters of the examined females.

Due to the fact that the females comprising cluster 1 were found to exhibit an increased strength lev- el of certain psychological characteristics and bodyrelated attitudes, as well as a tendency towards neurotic responses (maturity fear), they were referred to as neurotic. The females proved to display a high, inappropriate level of the following variables: discrepancy between current and ideal body image; three socio-cultural attitudes (pressure of socio-cultural norms, internalization of norms and exposure to media information concerning body image); and maturity fear. The research results confirmed negative body image, and a high level of internalization of socio-cultural norms and social pressure regarding body and appearance in the group of neurotic subjects. Moreover, the females revealed a high level of maturity fear. The values of other psychological and socio-cultural variables obtained in the aforementioned cluster of subjects proved to be elevated (i.e. inappropriate, but still lower than the values of the variables described above). It was also found that neurotic females were the only study subjects in the research population whose interoceptive awareness reached the level defined as borderline between average and inappropriate, which denotes lack of significant deficits in the process of recognizing and responding to emotional states and body sensations. As far as interpersonal distrust is concerned, its level among neurotic participants was discovered to be similar to that exhibited by the females in other clusters. A neurotic group was predominated by females diagnosed with binge eating disorder and bulimia nervosa. No subjects classified as neurotic exhibited symptoms of the restrictive type of anorexia nervosa. There were a few females suffering from bulimia-type anorexia in the aforementioned group.

Analysis of the research data indicated that the females comprising cluster 2 exhibited a high level of perfectionism, the fear of gaining weight and maturity fear. Thus the group was referred to as perfectionist. The females belonging to this sample revealed a very high, inappropriate level of slim body ideal, which was accompanied by an equally high degree of body dissatisfaction and a low level of interoceptive awareness. The indicators of self-evaluation (the feelings of ineffectiveness and inadequacy, as well as insecurity and interpersonal distrust) reached the mean values interpreted as elevated (the so-called clinically elevated level).

Examining the data gathered in the group of females defined as perfectionist, concerning the participants' self-evaluation of their actual body image, it was found that the females were the only research subjects whose scores were interpreted as low (adequate). However, the scores obtained by the females for the ideal body image proved to be high, which points to their preference for an ideal body shape. A similar tendency was observed in the individuals comprising other clusters. It was discovered that although the perfectionists were the slimmest study 
participants, which was proven by their mean BMI value, the females' desired (ideal) body figure was still thinner than their current body shape (in Thompson's Figure Test the examined women most frequently selected the most emaciated figure). From the above observations it follows that the body image evaluation and perception in the group of females classified as perfectionist corresponded to their actual body size and appearance, however, analysis of the research data also revealed the individuals' excessive desire for an emaciated (ideal) body image. This suggests that the females diagnosed with restrictive anorexia nervosa are likely to exhibit adequate perception of their current body: they are thin and in Thompson's Figure Test, when choosing the silhouette most resembling their own body shape, they point to a thin figure. It remains to be seen if the aforementioned findings are characteristic of a group of females who have been undergoing treatment therapy and thus are more ego-dystonic in their thoughts about their own feelings and internal states. It may well be that the females resort to defence mechanisms (e.g. denial) and hide their real feelings from others. Due to the fact that the present study was conducted on a relatively small sample, the issue requires further investigations in larger samples of individuals diagnosed with restrictive eating pathologies. Analysis of the research data gathered in a group of females characterized as perfectionist revealed that the majority of the examined psychological and socio-cultural variables, especially emotional body dissatisfaction, the fear of gaining weight and perfectionism, reached inappropriate levels.

Clinical examination of the strength level of attitudes towards adoption of socio-cultural norms in the aforementioned type of research subjects indicated that their body self-evaluation is significantly affected by internalized cultural standards regarding appearance, which seems to confirm a high level of internalization in the examined individuals. The perfectionist females were also found to exhibit a high level of exposure to the mass media information concerning body image. The strength levels of the two aforementioned socio-cultural variables in the group of perfectionist subjects proved to be similar to those obtained by other clinical participants. However, the level of pressure of socio-cultural norms regarding appearance was found to be higher in perfectionists than in other types of females. Clinical examination concerning medical diagnosis of the study subjects revealed that cluster 2 was predominated by females suffering from restrictive and bulimia-type anorexia nervosa.

Analysis of the data obtained in the group of females who comprised cluster 3 revealed that the individuals were the only research subjects who exhibited an inappropriate level of the majority of the examined psychological characteristics and body-related behaviours. Due to a specific configuration of the examined variables the females in cluster 3 were classified into an impulsive type. As compared with the other three psychological types, impulsive subjects were most diverse in terms of psychological characteristics. The cluster was predominated by females diagnosed with bulimia-type anorexia nervosa and bulimia nervosa, who obtained high or very high scores for the majority of the examined psychological and socio-cultural variables, including components of cognitive and emotional body negation, the fear of gaining weight, a high level of bulimia, low interoceptive awareness, a high level of perfectionism and low self-evaluation (the feeling of ineffectiveness and inadequacy). The last of the aforementioned psychological variables proved to be the only one whose mean value obtained by the females in cluster 3 reached a high clinical level, which seems to confirm a high level of worthlessness and the feelings of ineffectiveness and inadequacy among the subjects referred to as impulsive, suffering from anorexia nervosa as well as bulimia nervosa. Clinical analysis of the impact of socio-cultural factors (e.g. pressure, internalization and exposure to information regarding body image) on body image and appearance among the females in cluster 3 indicates that the individuals' body self-perception is significantly affected by internalized, socio-cultural standards of appearance (internalization), as well as extrinsic factors of social influence (independent search for information regarding body image, and social pressure). The mean values for the indicators of the three examined socio-cultural attitudes, obtained in the group of females defined as impulsive, point to a very high level of the investigated variables among the aforementioned individuals, which was not observed in other clusters of research subjects.

A significant difference was detected between impulsive individuals and the females classified into other psychological types in terms of maturity fear. The scores for the aforementioned variable obtained by the subjects referred to as impulsive were found to be the lowest in the whole population of the examined females suffering from eating disorders. Nevertheless, the mean value of the variable in this group denotes an elevated clinical level of maturity fear, which proves to be significantly different from the level exhibited by other research participants.

The fourth cluster of the examined females with eating disorders was referred to as adolescent-narcissistic due to the average age of the study subjects, as well as a specific configuration of their psychological characteristics and the strength level of desire for an ideal body shape. The cluster consisted predominantly of females diagnosed with binge eating disorder. A sizeable minority of the adolescent-narcissistic group were individuals suffering from a restrictive type of anorexia nervosa and bulimia nervosa. Analysis of the research data revealed that the females
A psychological typology anorexia, bulimia 
Bernadetta Izydorczyk comprising the aforementioned cluster exhibited high, inappropriate levels of body dissatisfaction and negative body image (distorted perception of the current body image and an excessive desire for an ideal body shape); a very high level of the fear of gaining weight, accompanied by an equally high level of drive for thinness; low interoceptive awareness; a high level of perfectionism; as well as a high level of maturity fear (a similar tendency was observed among neurotic and perfectionist study participants). It was also discovered that adolescent-narcissistic individuals displayed a high level of internalized socio-cultural norms regarding body image as well as a high degree of social pressure, and they were frequently exposed to mass media information concerning body and appearance. Compared to the females classified into other psychological types, the individuals comprising cluster 4 proved to exhibit the highest level of body dissatisfaction. The average age of the subjects pointed to the individuation-separation process, which is likely to explain the development of eating pathologies in this group of females, who seem to have experienced unresolved conflicts characteristic of the aforementioned developmental period.

The following observations can be made based on the psychometric and clinical examination of those of the examined psychological and socio-cultural variables which proved to reach the highest strength levels and significantly differentiated the examined females: 1) some of the investigated variables proved to reach a similar strength level in all of the four clusters of females distinguished as a result of k-means analysis of the research data;

2) it was possible to identify the variables which significantly differentiated four clusters of females distinguished as a result of k-means analysis of the research data.

It was also shown that all study subjects except neurotic individuals exhibited a similar, high and inappropriate level of body dissatisfaction, the fear of gaining weight, drive for thinness, perfectionism, interoceptive awareness deficits, and maturity fear. It is worth noting that the females classified into perfectionist and adolescent-narcissistic types were found to display a very high level of perfectionism. Such psychological variables as a tendency towards bulimia and low self-evaluation, defined as the feelings of ineffectiveness, inadequacy and self-worthlessness, emerged as the factors which significantly differentiated the females in the four clusters. The two aforementioned psychological variables proved to reach high values (high clinical values, referred to as inappropriate) only in impulsive individuals. The females in the other three clusters were found to exhibit an elevated level of the variables mentioned above.

The results of this investigation indicate that socio-cultural attitudes towards body and appearance turned out to be the least significant indicator of di- versity within the examined population of females suffering from anorexia nervosa, bulimia nervosa and binge eating disorder. The level of internalization and pressure of socio-cultural norms regarding body image and the level of exposure to media information concerning appearance were found to be similar among the females in all distinguished psychological types. They proved to be high and very high in all study subjects.

Based on the research data, it was possible to specify several essential criteria describing the distinguished psychological types of females with eating disorders, which are presented in Table 3.

\section{CONCLUSIONS}

Due to significant differences between the examined females in terms of the strength levels and the configuration of psychological and socio-cultural variables investigated in the present study, the study participants were classified into four different psychological types referred to as neurotic, perfectionist, impulsive and adolescent-narcissistic. The aforementioned psychological typology of females suffering from eating disorders was created irrespective of the individuals' medical diagnoses suggesting the symptoms of anorexia nervosa, bulimia nervosa or binge eating disorder.

Analysis of the research data indicated that the females classified into the particular psychological types are likely to exhibit symptoms of different eating disorders. The results of the current research show that medical classifications fail to provide sufficient criteria for describing a psychological profile and body image, which is an indispensable element in the diagnosis and treatment of individuals with eating disorders. It is recommended that further research be undertaken to deepen and clarify the psychological typology presented in this paper, which would considerably facilitate the process of diagnosis and treatment of individuals suffering from anorexia nervosa, bulimia nervosa and binge eating disorder.

The present findings can prove useful in developing effective programmes of psychological treatment for individuals diagnosed with eating disorders. The programmes should be based on various forms of therapeutic activities, depending on the psychological type of the patient (perfectionist, impulsive or neurotic). In the case of impulsive individuals it is recommended that long-term treatment (including psychological therapy) be combined with cognitive-behavioural therapy aimed at eliminating impulsive symptoms, whereas long-term therapy based on attachment, involving therapeutic interventions aimed at reducing increased perfectionism seems to be an effective form of psychological treatment for patients classified into a perfectionist type. Adolescent-narcissistic and neu- 
Table 3

Characteristics of psychological types of females with eating disorders, distinguished as a result of the present research

\begin{tabular}{|c|c|c|c|}
\hline Neurotic type & Perfectionist type & Impulsive type & $\begin{array}{c}\text { Adolescent-narcissistic } \\
\text { type }\end{array}$ \\
\hline $\begin{array}{l}\text { An increased level of } \\
\text { body dissatisfaction } \\
\text { and rejection }\end{array}$ & $\begin{array}{l}\text { A high level of body } \\
\text { dissatisfaction and } \\
\text { rejection }\end{array}$ & $\begin{array}{l}\text { A high level of body } \\
\text { dissatisfaction and } \\
\text { rejection }\end{array}$ & $\begin{array}{l}\text { A very high level of } \\
\text { body dissatisfaction } \\
\text { and rejection }\end{array}$ \\
\hline $\begin{array}{l}\text { Actual body image } \\
\text { dominated by ideal one }\end{array}$ & $\begin{array}{l}\text { Actual body image } \\
\text { dominated by ideal one }\end{array}$ & $\begin{array}{l}\text { Actual body image } \\
\text { dominated by ideal one }\end{array}$ & $\begin{array}{l}\text { Actual body image } \\
\text { dominated by ideal one }\end{array}$ \\
\hline $\begin{array}{l}\text { An appropriate or } \\
\text { slightly decreased level } \\
\text { of interoceptive aware- } \\
\text { ness }\end{array}$ & $\begin{array}{l}\text { A significantly de- } \\
\text { creased (inappropriate) } \\
\text { level of interoceptive } \\
\text { awareness }\end{array}$ & $\begin{array}{l}\text { A significantly de- } \\
\text { creased (inappropriate) } \\
\text { level of interoceptive } \\
\text { awareness }\end{array}$ & $\begin{array}{l}\text { A significantly de- } \\
\text { creased (inappropriate) } \\
\text { level of interoceptive } \\
\text { awareness }\end{array}$ \\
\hline $\begin{array}{l}\text { An appropriate or } \\
\text { slightly increased level } \\
\text { of perfectionism }\end{array}$ & $\begin{array}{l}\text { A very high level of } \\
\text { perfectionism }\end{array}$ & $\begin{array}{l}\text { A very high level of } \\
\text { perfectionism }\end{array}$ & $\begin{array}{l}\text { A high level of perfec- } \\
\text { tionism }\end{array}$ \\
\hline $\begin{array}{l}\text { A slightly increased lev- } \\
\text { el of the fear of gaining } \\
\text { weight }\end{array}$ & $\begin{array}{l}\text { A very high level of the } \\
\text { fear of gaining weight }\end{array}$ & $\begin{array}{l}\text { A high level of the fear } \\
\text { of gaining weight }\end{array}$ & $\begin{array}{l}\text { A high level of the fear } \\
\text { of gaining weight }\end{array}$ \\
\hline $\begin{array}{l}\text { "Bulimic thoughts" } \\
\text { - within the normal } \\
\text { range or slightly in- } \\
\text { creased }\end{array}$ & $\begin{array}{l}\text { "Bulimic thoughts" } \\
\text { - within the normal } \\
\text { range or slightly in- } \\
\text { creased }\end{array}$ & $\begin{array}{l}\text { A high level of "bulimic } \\
\text { thoughts" }\end{array}$ & $\begin{array}{l}\text { "Bulimic thoughts" } \\
\text { - within the normal } \\
\text { range or slightly in- } \\
\text { creased }\end{array}$ \\
\hline $\begin{array}{l}\text { Appropriate self-eval- } \\
\text { uation }\end{array}$ & $\begin{array}{l}\text { Appropriate self-eval- } \\
\text { uation }\end{array}$ & $\begin{array}{l}\text { Significantly low } \\
\text { self-evaluation }\end{array}$ & $\begin{array}{l}\text { Appropriate self-eval- } \\
\text { uation }\end{array}$ \\
\hline $\begin{array}{l}\text { Lack of increased inter- } \\
\text { personal distrust and } \\
\text { insecurity }\end{array}$ & $\begin{array}{l}\text { Lack of increased inter- } \\
\text { personal distrust and } \\
\text { insecurity }\end{array}$ & $\begin{array}{l}\text { Lack of increased inter- } \\
\text { personal distrust and } \\
\text { insecurity }\end{array}$ & $\begin{array}{l}\text { Lack of increased inter- } \\
\text { personal distrust and } \\
\text { insecurity }\end{array}$ \\
\hline $\begin{array}{l}\text { A very high level of } \\
\text { maturity fear }\end{array}$ & $\begin{array}{l}\text { A very high level of } \\
\text { maturity fear }\end{array}$ & $\begin{array}{l}\text { Maturity fear within } \\
\text { the normal range }\end{array}$ & $\begin{array}{l}\text { A very high level of } \\
\text { maturity fear }\end{array}$ \\
\hline $\begin{array}{l}\text { A very high level of } \\
\text { internalization of } \\
\text { socio-cultural norms } \\
\text { regarding body image }\end{array}$ & $\begin{array}{l}\text { A high level of internal- } \\
\text { ization of socio-cultural } \\
\text { norms regarding body } \\
\text { image }\end{array}$ & $\begin{array}{l}\text { A very high level of } \\
\text { internalization of } \\
\text { socio-cultural norms } \\
\text { regarding body image }\end{array}$ & $\begin{array}{l}\text { A high level of internal- } \\
\text { ization of socio-cultural } \\
\text { norms regarding body } \\
\text { image }\end{array}$ \\
\hline
\end{tabular}

rotic patients, who compared to individuals classified into other psychological types exhibit a relatively low level of interoceptive awareness deficits and perfectionism, and higher self-evaluation, should receive insight-oriented psychotherapy.

Due to the relatively small sample size, restricted access to the research population, as well as limited availability of the methods of investigating the psychological variables related to the world and inner experience (the measurement of which proves to be difficult), the present research findings are subject to certain limitations. Considering the clinical nature of the current study, the present outcomes and findings cannot be transferred to larger populations. Hence, it is recommended that further research be undertaken in the area of psychological and socio-cultural variables and conducted in different populations of individuals with eating disorders, which is likely to verify the present findings and thus improve effectiveness of treatment in this group of patients.

\section{References}

Bee, H. (2004). Psychologia rozwoju człowieka [Psychology of human development]. Poznań: Wydawnictwo Zysk i S-ka.

Blos, P. (1967). The second individuation process in adolescence. Psychoanalytic Study of the Child, 22, 162-186.

Bulik, C. M., Tozzi, F., Anderson, C., Mazzeo, S. E., Aggen, S., \& Sullivan, P. F. (2003). The relation be-
A psychological typology anorexia, bulimia 
Bernadetta Izydorczyk tween eating disorders and components of perfectionism. American Journal Psychiatry, 160, 366-368.

Cash, T. F. (2011a). Cognitive-behavioral perspectives on body image. In: T. F. Cash \& L. Smolak (eds.), Body Image: A Handbook of Science, Practice, and Prevention (pp. 39-47). New York: Guilford Press.

Cash, T. F. (2011b). Crucial considerations in the assessment of body image. In: T. F. Cash \& L. Smolak (eds.), Body Image: A Handbook of Science, Practice, and Prevention (pp. 129-137). New York: Guilford Press.

Cash, T. F. (2002). Cognitive-behavioral perspectives on body image. In: T. F. Cash \& T. Pruzinsky (eds.), Body Image: A Handbook of Theory, Research, and Clinical Practice (pp. 38-47). New York, London: Guilford Press.

Cash, T. F., \& Pruzinsky, T. (eds.). (2002). Body image: A Hand-book of Theory, Research, and Clinical Practice. New York, London: Guilford Press.

Crowther, J. H., \& Sherwood, N. (1997). Assessment. In: D. M. Garner \& P. E. Garfinkel (eds.), Handbook of treatment for eating disorders (pp. 35-49). New York, London: Guilford Press.

Duncan, A. E., Neuman, R. J., Kramer, J., Kuperman, S., Hesselbrock, V., Reich, T., \& Bucholz, K. K. (2005). Are there subgroups of bulimia nervosa based on comorbid psychiatric disorders? International Journal of Eating Disorders, 37, 19-25.

Fairburn, C. G., \& Harrison, P. J. (2003): Eating disorders. Lancet, 361, 407-416.

Fredrickson, B. L., \& Roberts, T. A. (1997). Objectification theory.toward understanding women's lived experiences and mental health risks. Psychology of Women Quarterly, 21, 173-206.

Fredrickson, B. L., \& Harrison, K. (2005). Throwing like a girl: self-objectification predicts adolescent girls' motor performance. Journal of Sport and Social Issues, 29, 79-101.

Gajewski, P. (2013). Interna Szczeklika. Podręcznik chorób wewnętrznych [A Handbook of internal diseases]. Kraków: Medycyna Praktyczna.

Garner, D. M. (2004). EDI-3. Eating Disorders Inventory. Professional Manual. Florida Avenue - Lutz, USA: Psychological Assessment Resources, Inc.

Gerbner, G., Gross, L., Morgan, M., \& Signorielli, N. (1994). Growing up with television: The cultivation perspective. In: J. Bryant \& D. Zillmann (eds.), Media effects: Advances in theory and research (pp. 17-41). Hillsdale, NJ: Erlbaum.

Grilo, C. M. (2002). Recent research of relationship among eating disorders and personality disorders. Current Psychiatry Reports, 4, 18-24.

Grogan, S. (2008). Body Image. Understanding Body Dissatisfaction in Men, Women, and Children. London, New York: Routlege Psychology Press.

Hare-Mustin, R. T., \& Marecek, J. (1988). The meaning of difference: Gender theory, postmodernism, and psychology. American Psychologist, 43, 455-464.
Heinberg, L. J., Thompson, J. K., \& Stormer, S. (1995). Development and validation of the Sociocultural Attitudes Towards Appearance Questionnaire (SATAQ). International Journal Eating Disorders, 17, 81-89.

Izydorczyk, B. (2011c). A psychological profile of the bodily self characteristics in women suffering from bulimia nervosa. In: P. Hay (ed.), New insights into the prevention and treatment of bulimia nervosa (pp. 147-167). Croatia: InTech - Open Access Publisher.

Izydorczyk, B. (2010): Body image among young females with anorexia nervosa and the structure of body image among their mothers. Archives of Psychiatry and Psychotherapy, 2, 61-67.

Izydorczyk, B. (2011a). Psychologiczny profil cech ja cielesnego u młodych kobiet polskich - analiza porównawcza struktury ja cielesnego u kobiet chorych na zaburzenia odżywiania i zaburzenia psychotyczne i tych nie ujawniających zaburzeń psychicznych [Psychological profile of bodily self features of young Polish women - comparative analysis of bodily self structure of woman with eating disorders and psychosis]. Psychiatria Polska, 5, 653-670.

Izydorczyk, B. (2011b). A psychological diagnosis of the structure of the body self in a group. Archives of Psychiatry and Psychotherapy, 2, 21-30.

Izydorczyk, B. (2013). Selected psychological traits and body image characteristics in females suffering from binge eating disorder. Archives of Psychiatry and Psychotherapy, 1, 19-33.

Izydorczyk, B. (2014). Postawy i zachowania wobec wtasnego ciata w zaburzeniach odżywiania [Body-related attitudes and behaviours in eating disorders]. Warszawa: Wydawnictwo Naukowe PWN.

Jordan, J. V., Kaplan, A. C., Miller, J. B., Stiver, I. P., \& Surrey, J. L. (1991). Women's growth in connection: Writings from the Stone Center. New York: Guilford Press.

Józefik, B. (ed.). (1999). Anoreksja i bulimia psychiczna. Rozumienie i leczenie zaburzeń odżywiania się [Understanding and treatment of eating disorders]. Kraków: Wydawnictwo Uniwersytetu Jagiellońskiego.

Kołobo, H., \& Woynarowska, B. (2004). Samoocena masy ciała i odchudzanie się młodzieży w okresie dojrzewania [Self-perception of body mass and dieting in adolescents]. Przegląd Pediatryczny, 34, 196-201.

Krueger, D. W. (2002a). Psychodynamic perspective on body image. In: T. F. Cash \& T. Pruzinsky (eds.), Body Image: A Handbook of Theory, Research, and Clinical Practice (pp. 30-37). New York, London: Guilford Press.

Krueger, D. W. (2002b). Integrating Body Self and Psychological Self. Creating a New Story in Psycho- 
analysis and Psychotherapy. New York, London: Bruner-Routledge.

Lipowska, M., \& Lipowski, M. (2013). Polish normalization of the Body Esteem Scale. Health Psychology Reports, 1, 72-81. DOI: 10.5114/hpr.2013.40471

Lwow, F., Dunajska, K., \& Milewicz, A. (2007). Występowanie czynników ryzyka jadłowstrętu psychicznego i bulimii u 18-letnich dziewcząt [Anorexia and bulimia risk factors among 18-yearsold girls]. Endokrynologia, Otyłość i Zaburzenia Przemiany Materii, 3, 33-38.

McKinley, N. M., \& Hyde, J. S. (1996). The Objectified Body Consciousness Scale. Psychology of Women Quarterly, 20, 181-215.

Mikołajczyk, E., Samochowiec, J., Śmiarowska, M., \& Syrek, A. (2004). Cechy psychologiczne pacjentek z zaburzeniami odżywiania w porównaniu ze studentkami wyższych szkół medycznych badanych kwestionariuszem EDI [Psychological characteristics od female patients with eating disorders as compared with those exhibited by female medical school students examined using the EDI inventory]. Psychiatria Polska, 38 (Suppl.), 170-171.

Mikołajczyk, E., \& Samochowiec, J. (2004). Cechy osobowości u pacjentek z zaburzeniami odżywiania [Personality characteristics of female patients with eating disorders]. Psychiatria, 1, 91-95.

Ogińska-Bulik, N. (2004). Psychologia nadmiernego jedzenia. Przyczyny, konsekwencje, sposoby zmiany [Psychology of overeating. Causes, consequences, the ways of changing]. Łódź: Wydawnictwo UŁ.

Ogińska-Bulik, N., \& Chanduszko-Salska, J. (2000a). Lęk, gniew i radzenie sobie ze stresem u kobiet z nadwagą i otyłością [Anxiety, anger and coping with stress in overweight and obeses females]. Sztuka Leczenia, 4, 47-54.

Ogińska-Bulik, N., \& Chanduszko-Salska, J. (2000b). Psychologiczna charakterystyka kobiet z nadwagą i otyłością [Psychological characteristics of overweight and obese females]. Acta Universitatis Lodziensis. Folia Psychologica, 4, 35-44.

Thompson, J. K. (2004): Handbook of disorders and obesity. New Jersey: John Wiley \& Sons.

Thompson, J. K., \& Altabe, M. N. (1991). Psychometric qualities of the figure rating scale. International Journal of Eating Disorders, 5, 615-619.

Thompson, J. K., \& Berg, P. (2002): Measuring body image attitudes among adolescents and adults. In: T. F. Cash \& T. Pruzinsky (eds.), Body image. A handbook of theory, research, and clinical practice (pp. 142-153). New York, London: Guilford Press.

Thompson, J. K., \& Gray, J. J. (1995). Development and validation of a new body image assessment scale. Journal of Personality Assessment, 64, 258-269.

Thompson, J. K., \& Stice, E. (2001): Thin-ideal internalization: Mounting evidence for a new risk factor for body image disturbance and eating pathol- ogy. Current Directions in Psychological Science, 10, 181-183.

Thompson, J. K., \& Smolak, L. (2001). Body image, eating disorders, and obesity in youth: Assessment, Prevention, and Treatment. Washington, DC: American Psychological Association.

Tiggemann, M. (2003): Media exposure, body dissatisfaction and disordered eating: television and magazines are not the same. European Eating Disorders Review, 11, 418-430.

Wear, R. W., \& Pratz, O. (1987). Test-retest reliability for the disorder inventory. International Journal Eating Disorders, 6, 767-769.

Włodarczyk-Bisaga, K., Dolan, B., McCluskey, S., \& Lacey, H. (1995). Disordered eating behavior and attitudes towards weight and shape in Polish women. European Eating Disorders Review, 3, 205-216.

Wojtyła, A., Biliński, P., Bojar, I., \& Wojtyła, C. (2011). Zaburzenia odżywiania u polskich gimnazjalistów [Eating disorders among Polish adolescents attending junior high schools]. Problemy Higieny i Epidemiologii, 92, 343-350.

Wolf, N. (2000). Mit piękności [The Beauty Myth]. Biuletyn OŚKI, 3, 45-47.

Wolf, N. (2002). The Beauty Myth: How Images of Beauty Are Used Against Women (pp. 184-190). New York: Harper Collins.

Zurbriggen, E. L., Collins, R. L., Lamb, S., Roberts, T.-A., Tolman, D. L., Ward, L. M., \& Blake, J. (2010). Report of the APA Task Force on the Sexualization of Girls. www.apa.org/pi/women/programs/girls/ report-full.pdf

Żabiński, M. F., Pung, M. A., Wilfley, D. E., Eppstein, D. L., Winzelberg, A. J., Celio, A., Taylor, C. B. (2001). Reducing risk factors for eating disorders: targeting at-risk women with a computerized psycho-educational program. International Journal of Eating Disorders, 29, 401-408.

Żechowski, C. (2008). Polska wersja Kwestionariusza Zaburzeń Odżywiania (EDI) - adaptacja i normalizacja [Polish Version of Eating Disorder Inventory (EDI) - adaptation and normalization]. Psychiatria Polska, XLII, 179-192.
A psychological typology anorexia, bulimia 